\title{
Kepuasan Pengunjung Museum Pusat TNI AD Dharma Wiratama Serta Konsep Pengembangannya
}

\author{
Aisha Astriecia \\ Universitas Gadjah Mada \\ Email: aisha.astriecia@gmail.com
}

\begin{abstract}
Museum Pusat TNI AD Dharma Wiratama, located in Yogyakarta, is managed by TNI. The specialty of this museum lies in the collection of objects, which only displays historical objects associated with the struggle of soldiers in the struggle for RI's independence. The museum is under the supervision of the Army History Service rather than the Tourism Department, thus the museum does not have admission fees and guide fees for visitors. This is due to the prohibition of collection or fees from Disjarahad.

This study aims to analyze and determine the level of visitor satisfaction based on product quality, availability of facilities, and services, development potential, and the problems contained in this museum. Data will be analized to find some concepts for developing tourism so that, the museum can increase its tourists visit. The research method is descriptive methode and data are analyzed quantitative and qualitative method. Quantitative data was obtained by distributing questionnaires while qualitative data was obtained by conducting interviews as a tool in verifying the questionnaire data.

Based on the result of research, it is known that most visitors of Museum Pusat TNI AD Dharma Wiratama are satisfied with product quality and service provided, yet some visitors are unsatified with its facilities. In addition, this museum has the potential to be developed in the direction of educational tourism history when viewed from the type of tourists and its location. This museum also needs to do promotion to the surrounding schools and universities so that visits to this museum can increase.
\end{abstract}

Keywords: satisfaction, visitor,tourism, museum, psychology, tourist

\section{Pendahuluan}

Museum Dharma Wiratama merupakan salah satu museum di Yogyakarta yang khusus menyimpan koleksi peninggalan tentara Indonesia dalam memperjuangkan kemerdekaan Indonesia. Museum merupakan sebuah tempat penyimpanan benda bersejarah yang dapat dimanfaatkan sebagai sarana pendidikan, rekreasi, maupun penelitian. Namun, museum saat ini belum memperoleh tempat yang sewajarnya sebuah atraksi wisata maupun tempat menambah ilmu pengetahuan. Permasalahannya, suatu museum sering hanya ditempatkan dalam posisi yang tidak berbeda dengan artshop atau gallery, indah tapi kurang informatif(Axioma, 2002 dalam Yoeti, 2006: 12). Kurangnya informasi dari produk yang dipamerkan oleh museum kemudian dapat berpengaruh pada kepuasan pengunjung yang datang.

Pengunjung merupakan orang yang melakukan perjalanan atau berkunjung ke suatu destinasi wisata baik menginap maupun tidak di daerah tujuannya. Jumlah kunjungan merupakan salah satu faktor yang menentukan meningkatnya pendapatan serta keberlanjutannya suatu museum. 
Maka, keberadaan dan kepuasan pengunjung harus diperhatikan. Namun, kepuasan pengunjung sebelum, sesaat, dan setelah mengunjungi museum cenderung terlupakan oleh pengelola. Rasa ketidakpuasan dari pengunjung dapat menjadi salah satu faktor penyebab suatu museum cenderung terlihat sepi. Museum yang memiliki koleksi pameran unik, lokasi strategis, dan harga tiket yang terjangkau menjadi pertimbangan kedatangan pengunjung. Namun di sisi lain, pelayanan dan fasilitas yang baik juga diperlukan untuk menunjang kepuasan pengunjung.

Berdasarkan faktor aksesibilitas, Museum Dharma Wiratama berada di lokasi yang strategis, namun apabila melintasi museum ini cenderung sepi. Hal tersebut berbanding terbalik dengan data jumlah kunjungan wisatrawan. Hal ini menimbulkan fenomena yang unik karena kawasan sekitaran museum selalu ramai namun, museum ini selalu nampak sepi. Lokasi museum yang berdekatan dengan universitas, sekolah, serta toko buku, menunjukkan potensi museum ini sebagai salah satu wisata edukatif. Selanjutnya dapat dilihat pula berdasar karakteristik pengunjung museum yang didominasi oleh rombongan pelajar. Museum ini dapat pula dikatakan sebagai tempat wisata edukatif karena museum ini dapat merupakan tempat rekreasi dan juga memiliki banyak ilmu pengetahuan.

Banyaknya ilmu yang diperoleh dalam durasi yang singkat cenderung mengakibatkan kejenuhan pada pengunjung (Melton,1972 via Ross,1998: 162). Kejenuhan tersebut diakibatkan oleh banyaknya pengetahuan baru yang harus ditangkap dalam waktu yang singkat. Apabila telah merasa lelah dan jenuh pengunjung malah akan mengantuk dan mencari pintu keluar atau dengan kata lain mengakhiri kunjungan tersebut. Kejenuhan yang dialami pengunjung bisa jadi dikarenakan penjelasan yang membingungkan, objek yang dipamerkan kurang baik, dan lain sebagainya. Kejenuhan ini bisa menjadi awal dari ketidakpuasan kunjungan. Keadaan ini sebaiknya menjadi pertimbangan bagi pengelola agar dapat mengatasi kejenuhan dan ketidakpuasan pengunjung dari berbagai aspek. Faktor yang meyebabkan ketidakpuasan pengunjung berhubungan dengan tidak terpenuhinya kebutuhan dasar yang diperoleh wisatawan seperti pelayanan, kualitas objek, kelengkapan fasilitas, dan lain sebagainya (Gage, 2006)

Museum Pusat TNI AD secara geografis memiliki posisi yang strategis sebegai salah satu tujuan wisata di Yogyakarta. Posisi museum cenderung strategis karena terletak di pusat kota Yogyakarta dengan jarak 3,2 kilometer atau 10 menit dari ikon wisata Yogyakarta yaitu Tugu Paal Putih. Selain itu, museum ini juga terletak berdekatan dengan kawasan pendidikan seperti universitas, sekolah, dan perpustakaan kota. Namun pada kenyataannya, museum ini cenderung terlihat sepi baik pada hari kerja maupun hari libur. Berdasarkan fenomena tersebut, tujuan penelitian ini adalah 1 . Mengetahui tingkat kepuasan pengunjung terhadap kualitas produk, pelayanan, dan fasilitas yang tersedia di Museum Pusat TNI AD, 2. Mengetahui hambatan dan tantangan dalam pengembangan Museum Pusat TNI AD sebagai destinasi wisata, 3. Memberikan arahan pengembangan berdasarkan kualitas produk, pelayanan, dan ketersediaan fasilitas.

\section{Landasan Teori}

\subsection{Destinasi Wisata}

Destinasi wisata secara umum terbagi atas tiga jenis yaitu destinasi wisata alam, budaya, dan buatan atau minat khusus. Wisata budaya adalah jenis wisata yang memanfaatkan potensi hasil budaya manusia sebagai objek daya tariknya. Daya tarik di dalam wisata budaya dapat berupa seni pertunjukan, cara pembuatan batik, proses pembuatan perak, dan juga yang berupa peninggalan bersejarah seperti di museum ataupun monumen. Menurut Pitana dan Diarta (2009), sumber daya budaya yang bisa dikembangkan menjadi daya tarik wisata di antaranya bangunan bersejarah, situs, monumen, museum, galeri seni, ataupun situs budaya kuno.

Setelah membahas wisata budaya yang menjadikan kebudayaan sebagai daya tarik wisata ada pula wisata alam menggunakan elemen dari alam sebagai daya tarik. Elemen dari alam yang menjadi daya tarik wisata dapat berupa pepohonan, udara, pegunungan, ataupun bentang alam lainnya.

Setelah wisata alam dan budaya, muncul pula jenis wisata baru yaitu wisata minat khusus. Jenis wisata berbeda dengan kedua wisata sebelumnya 
yang sebagian besar memanfaatkan sesuatu yang telah ada sebagai daya tarik. Wisata minat khusus menarik wisatawan secara lebih personal seperti dari hobi (arena golf, wisata pemancingan), bisnis (MICE), lifestyle (spa), dan lain sebagainya.

\subsection{Wisatawan dan Pengunjung}

Beberapa jenis wisatawan dapat dikategorisasikan sebagai berikut:

- Traveller merupakan seseorang yang melakukan perjalanan lebih dari dua tempat.

- Visitor merupakan seseorang yang melakukan perjalanan ke daerah yang bukan merupakan tempat tinggalnya dalam kurun waktu kurang dari 12 bulan dan bertujuan tidak lain untuk melakukan kegiatan wisata.

- Tourist merupakan bagian dari visitor atau pengunjung yang menghabiskan waktu sedikitnya satu hariu atau 24 jam di daerah yang dikunjungi (Pitana, 2005; WTO, 1995).

\subsection{Kepuasan Pengunjung}

Pengunjung pada suatu destinasi pariwisata memiliki kesamaan dengan konsumen pada sebuah perusahaan baik jasa maupun barang. Pengunjung juga dapat dikatakan sebagai konsumen karena mereka sama-sama menikmati atau mengonsumsi barang atau jasa yang disediakan oleh penyedia jasa. Mengonsumsi sesuatu bukan hanya dalam konteks makan ataupun minum tetapi juga menggunakan ataupun menikmati jasa yang ada. Memberikan pelayanan yang maksimal untuk pengunjung dapat menjadi pendorong adanya kepuasan setelah aktivitas kunjungaan. Menurut Kotler (dalam Rangkuti, 2006: 23) kepuasan pelanggan merupakan ungkapan perasaan senang ataupun kecewa sebagai hasil dari perbandingan antara keadaan nyata yang dirasakan atau produk yang dirasakan dengan harapan seseorang sebelum mendapatkan suatu pengalaman.

Hasil perasaan puas dari pengunjung atau wisatawan tersebut dapat memunculkan sebuah customer referrals. Costumer referrals merupakan ketersediaan pelanggan untuk memberitahukan kepuasan yang mereka nikmati kepada orang lain. Kegiatan ini berarti promosi gratis dari mulut ke mulut karena pelanggan tersebut dengan senang hati merekomendasikan apa yang suatu pengamalan atau tempat yang telah dirasakannya kepada orang terdekat, seperti keluarga atau teman. Perasaan puas yang dirasakan pelanggan akan berdampak baik seperti kedatangan kembali pelanggan tersebut bersama kerabat. (Rangkuti, 2006: 6).

Kepuasan pengunjung merupakan tanggung jawab dari seluruh pengelola destinasi wisata. Pemberian pelayanan yang tepat menjadi salah satu faktor yang mempengaruhi tingkat kepuasan pengunjung. Kepuasan pengunjung atau wisatawan dapat diuraikan menjadi tiga tahap, yaitu pertama menentukan kebutuhan pokok wisatawan, kedua mencari tahu harapan wisatawan, dan ketiga memenuhi semua harapan wisatawan.

Untuk memenuhi kepuasan pengunjung, pengelola sebuah destinasi wisata harus mengetahui kebutuhan pengunjung atau wisatawan tersebut. Menurut Yoeti (1999) kebutuhan wisatawan adalah kebutuhan manusia yang sedang dalam perjalanan mencari kesenangan, jauh dari tempat kediamannya, dan semata-mata sebagai konsumen di DTW yang di kunjunginya. Sedangkan Moslow (dalam Yoeti, 1999) mengatakan bahwa kebutuhan manusia itu bertingkat-tingkat, mulai dari yang umum, sampai pada hal-hal yang bersifat individual. Berdasarkan analogi dari teori Moslow kebutuhan wisatawan dapat diurutkan sebagai berikut:

- Kebutuhan akan informasi

- Kebutuhan akan pelayanan angkutan

- Kebutuhan akan makan dan minum selama dalam perjalanan

- Kebutuhan melihat sesuatu yang aneh, yang unik yang belum pernah ia lihat atau yang berbeda dari yang pernah ia saksikan

- Kebutuhan beristirahat, bersantai, relaksasi, bersenang-senang, berolah raga, dan bercengkrama dengan teman-teman lain

- Kebutuhan untuk berbelanja

- Kebutuhan untuk dokumentasi

Di dalam memenuhi kepuasan pengunjung cenderung sulit karena tingkat kepuasan tiap pengunjung berbeda-beda. Oleh karena itu pelayanan serupa pada setiap pengunjung tidak dapat diterapkan. Untuk mengetahui keinginan pengunjung, pengelola dapat memosisikan diri sebagai pengunjung. Hal tersebut merupakan cara paling sederhana untuk melihat tingkat pelayanan yang diberikan. Menurut Gage (2006) secara umum, para pelanggan atau pengunjung menginginkan hal 
sederhana seperti produk atau jasa yang berkualitas, aksesibilitas, dan pelayanan pelanggan yang baik.

\subsection{Jasa Pelayanan}

Pelayanan jasa merupakan cara atau tindakan dari suatu pihak untuk memenuhi kebutuhan pihak lain dan memperoleh imbalan sebagai balasannya. Imbalan yang diperoleh tidak hanya dalam bentuk barang atau pemberian kasat mata secara langsung. Imbalan juga dapat berupa kepuasan atau perasaan senang dari pengunjung atau pelanggan yang datang. Pelayanan bersifat tak terlihat (intangible) dan didapat bukan berdasarkan kepemilikan atas sesuatu yang mungkin atau tidak mungkin berhubungan dengan suatu produk tertentu (Pitana dan Diarta, 2009:128). Dalam industri pariwisata jasa pelayanan merupakan salah satu yang ditawarkan untuk pengunjung. Pelayanan yang dapat memuaskan pengunjung merupakan pelayanan yang memiliki kualitas yang baik. Di samping menawarkan produk wisata yang menarik dan bagus, pelayanannya pun harus seimbang. Morley (dalam Ross, 1998: 9) yakin dampak fasilitas dan pelayanan pada wisatawan pada umumnya diabaikan, padahal dampak itu bisa memainkan peranan yang sangat penting, bukan hanya untuk wisatawan sendiri, tetapi juga bagi permintaan, melalui penyebaran informasi dari mulut ke mulut, saran dan kunjungan ulang.

Kualitas dalam pelayanan merupakan faktor yang penting untuk meningkatkan kepuasan pengunjung. Kualitas itu sendiri adalah totalitas dari hubungan antara penyedia jasa atau layanan (functional aspects) dengan karakteristik produk (technical aspects) yang menjamin kepuasan konsumen (Cooper et al,. 1999: 359 via Pitana dan Diarta, 2009:160). Sedangkan menurut Rangkuti (2006) kualitas jasa didefinisikan sebagai penyampaian jasa yang akan melebihi tingkat kepentingan pelanggan. Jenis kualitas yang digunakan untuk menilai kualitas jasa adalah sebagai berikut:

- Kualitas teknik (outcome), yaitu kualitas hasil kerja penyampaian jasa itu sendiri.

- Kualitas pelayanan (proses), yaitu kualitas cara penyampaian jasa tersebut.

Selain menjabarkan mengenai jenis-jenis kualitas, Rangkuti (2006) juga membahas mengenai dimensi kualitas jasa. Terdapat 10 kriteria umum atau standar yang menentukan kualitas suatu jasa, yaitu 1)Reliability (keandalan), 2)Responsiveness (ketanggapan), 3)Competence (kemampuan), 4) Access (mudah diperoleh), 5)Courtesy (keramahan), 6)Communication (komunikasi), 7Credibility (dapat dipercaya), 7)Security (keamanan), 8) Understanding (knowing the customer) (memahami pelanggan), dan 9)Tangibles (bukti nyata kasat mata)

\subsection{Museum}

Museum merupakan sebuah bangunan yang digunakan untuk menyimpan ataupun memamerkan benda-benda bersejarah atau benda-benda seni lainnya. Museum adalah sebuah lembaga yang bersifat tetap, tidak mencari keuntungan, melayani masyarakat dan perkembangannya terbuka untuk umum, yang memperoleh, merawat, menghubungkan dan memamerkan, untuk tujuantujuan studi, pendidikan dan kesenangan, barangbarang pembuktian manusia dan lingkungannya (Sutaarga, 1997:15-16). Sedangkan menurut ICOM, museum adalah sebuah lembaga yang bersifat tetap, tidak mencari keuntungan, melayani masyarakat dan perkembangannya, terbuka untuk umum, memperoleh, merawat, menghubungkan dan memamerkan artefak-artefak perihal jati diri manusia dan lingkungannya untuk tujuan studi, pendidikan dan rekreasi.

Adanya sebuah museum di suatu tempat selain memiliki tujuan yang telah disebut di atas, museum juga memiliki beberapa fungsi. ICOM mengemukakan 9 fungsi museum, sebagai berikut:

1. Pengumpulan dan pengamatan warisan alam dan budaya,

2. Dokumentasi dan penelitian ilmiah

3. Konservasi dan preservasi,

4. Penyebaran dan pemerataan ilmu untuk umum,

5. Pengelanan dan penghayatan kesenian,

6. Pengenalan kebudayaan antar daerah dan antar bangsa,

7. Visualisasi warisan alam dan budaya,

8. Cermin pertumbuhan peradaban umat manusia,

9. Pembangkit rasa bertakwa dan bersyukur kepada Tuhan Yang Maha Esa. 
Sebuah museum harus dikelola denagn baik dan memiliki badan hukum. Pengelola sebuah museum bisa dari pemerintah setempat ataupun pihak swasta. Di dalam mendirikan dan mengelola sebuah museum bukanlah hal yang mudah. Pendiri ataupun badan yang bersangkutan dengan pendirian museum harus mengetahui keperluan-keperluan umum adanya sebuah museum.

\section{Metode Penelitian}

Penelitian ini menggunakan metode deskriptif dengan analisis data kombinasi kuantitatif dan kualitatif. Hasil temuan data secara kuantitatif diperoleh dari penyebaran kuisioner kepada 100 orang responden, sedangkan data kuantitatif diperoleh melalui wawancara kepada beberapa responden. Wawancara dilakukan untuk memverifikasi pilihan jawaban dari responden. Pengambilan data di dalam penelitian ini dilakukan pada hari kerja dan akhir pekan atau hari libur sehingga data yang diperoleh lebih variatif.

\section{Hasil Penelitian}

\subsection{Struktur Responden Berdasarkan Jumlah Kunjungan}

Berdasarkan observasi, pengunjung terbagi atas 3 kategori yaitu kelompok besar, kelompok sedang, dan kelompok kecil atau individual. Kunjungan dalam kelompok besar adalah rombongan pengunjung yang datang menggunakan bus, kunjungan ini dilakukan dengan membuat janji sebelumnya. Kunjungan dalam kelompok sedang merupakan kunjungan keluarga maupun rombongan dalam jumlah lebih kecil. Kunjungan pada kelompok sedang ini pada umumnya menggunakan mobil ataupun motor dalam jumlah lebih dari 2. Kategori terakhir adalah kunjungan dalam kelompok kecil atau individual. Pengunjung pada kelompok ini pada umumnya menggunakan satu atau dua motor atau kendaraan umum.

\subsection{Kualitas Produk Museum}

Kualitas produk museum merupakan salah satu faktor untuk mengukur tingkat kepuasan dan kenyamanan pengunjung. Variabel yang dijadikan ukuran dalam hal ini bukan hanya koleksi yang dipameran di museum saja tetapi juga kebersihan bangunan, kenyamanan dalam museum, serta keterangan yang terdapat pada koleksi. Perasaaan nyaman selama melakukan kunjungan dapat mempengaruhi konsentrasi dalam mendengarkan penjelasan pemandu maupun dalam menikmati setiap koleksi yang ada. Keadaan yang tidak panas dan tidak pengap serta penerangan yang cukup.

Tabel 4. Kualitas produk museum

\begin{tabular}{|c|c|c|c|c|}
\hline & Kualitas Produk & Puas & Cukup & $\begin{array}{c}\text { Tidak } \\
\text { puas }\end{array}$ \\
\hline A & $\begin{array}{c}\text { Kenyamanan di } \\
\text { dalam museum }\end{array}$ & 78 & 22 & 0 \\
\hline B & Kebersihan ruangan & 86 & 14 & 0 \\
\hline C & Kualitas koleksi & 81 & 19 & 0 \\
\hline D & $\begin{array}{c}\text { Kejelasan keterangan } \\
\text { pada koleksi }\end{array}$ & 80 & 20 & 0 \\
\hline
\end{tabular}

Sumber: Analisis, 2013

Berdasarkan hasil kuisioner di atas dapat diketahui bahwa pengunjung sudah puas terhadap kenyamanan selama berada di dalam museum yaitu sebesar 78 persen. Perasaan puas terhadap kenyamanan di museum berhubungan langsung dengan kebersihan yang merupakan variabel kedua. Sebanyak 86 persen pengunjung merasa puas terhadap kebersihan museum. Berdasarkan hasil wawancara kepada pengunjung rombongan, museum sangan nyaman dikunjungi oleh rombongan pelajar sekolah dasar karena ruangan koleksi luas, bersih dan memiliki sirkulasi udara yang baik.

Variabel ketiga dan keempat berhubungan dengan koleksi yang dimiliki museum. Variabel ketiga adalah kualitas dari koleksi museum. Variabel ini memiliki nilai yang baik yaitu 81 persen. Kemudian variabel keempat merupakan kejelasan keterangan pada koleksi. Berdasarkan hasil wawancara dari pengunjung individual, responden dapat menikmati kunjungan dan melihatlihat koleksi museum tanpa adanya pemandu. Hal tersebut dikarenakan koleksi yang terpajang rapi dan memiliki keterangan secara tertulis pada setiap koleksinya.

\subsection{Fasilitas Museum}

Fasilitas yang dimiliki Museum Dharma Wiratama 
di antaranya area parkir, mushola, toilet, dan lain sebagainya. Tabel di bawah ini merupakan hasil yang menunjukkan tingkat kepuasan pengunjung terhadap fasilitas di Museum Dharma Wiratama.

Tabel 5. Kepuasan atas fasilitas museum

\begin{tabular}{|c|c|c|c|c|}
\hline & Fasilitas & Puas & Cukup & $\begin{array}{c}\text { Tidak } \\
\text { puas }\end{array}$ \\
\hline A & Kemudahan parkir & 74 & 24 & 2 \\
\hline & $\begin{array}{c}\text { Kebersihan dan } \\
\text { kenyamanan } \\
\text { mushola dan toilet }\end{array}$ & 54 & 45 & 1 \\
\hline C & $\begin{array}{c}\text { Kemudahan memperoleh } \\
\text { makanan dan minuman }\end{array}$ & 18 & 43 & 39 \\
\hline D & $\begin{array}{c}\text { Kejelasan petunjuk arah } \\
\text { dalam ruangan pameran }\end{array}$ & 73 & 24 & 3 \\
\hline E & $\begin{array}{c}\text { Kecukupan fasilitas } \\
\text { yang tersedia }\end{array}$ & 60 & 38 & 2 \\
\hline
\end{tabular}

Sumber: Analisis, 2013

Berdasarkan data table di atas, pengunjung merasa puas terhadap ketersediaan fasilitas parker. Sebagai salah satu destinasi wisata pendidikan, Museum Darma Wiratama meyediakan halaman parkir yang luas. Area parkir di museum ini dapat menampung sampai dengan 5 unit bus pariwisata. Keunggulan fasilitas parkir berdampak pada adanya rutinitas kunjungan wisata dari Sekolah Dasar (narasumber, 2013). Berdasarkan responden individual, luasnya lahan parkir di museum ini cenderung mengakibatkan kebingungan. Hal tersebut diakibatkan tidak adanya papan informasi atau penunjuk tempat parkir. Kondisi tersebut juga diperburuk dengan pemanfaatan lahan parkir untuk karyawan Gramedia (toko buku di seberang museum), sehingga mengakibatkan wisatawan salah parkir di area parkir karyawan.

Penilaian kualitas pada variabel kedua adalah pada fasilitas toilet dan ketersediaan mushola. Berdasarkan data kuisioner, hasil penilaian wisatawan terkait variabel kedua tidak sebaik variabel pertama. Perbedaan presentase pengunjung yang merasa puas dan tidak puas tidak signifikan. Hal tersebut dikarenakan toilet yang tersedia juga dimanfaatkan untuk penyimpanan alat kebersihan seperti pel dan ember pel selain itu ada beberapa toilet dengan kodisi gelap dan tidak berkunci sehingga mengakibatkan ketidaknyamanan pengunjung. Sedangkan mushola yang tersedia juga dinilai kurang nyaman karena kondisi alat ibadah yang kurang terawat (narasumber, 2013).

Penilaian pada poin atau variabel ketiga yaitu kemudahan memperoleh makanan dan minuman menjadi poin dengan presentase kepuasan terendah. Ketidakpuasan wisatawan disebabkan adanya peraturan terkait komersialisasi pada lingkungan TNI. Museum TNI AD selain berfungsi sebagai destinasi wisata juga berfungsi sebagai kantor administrasi TNI sehingga peraturan terkait komersialisasi masih diterapkan. Museum hanya dapat menyediakan koperasi, namun keberadaannya sering tidak terlihat wisatawan karena tidak adanya papan penanda. Pernyataan responden yang merasa puas terhadap kemudahan memperoleh makanan dan minuman dipengaruhi oleh keberadaan supermarket (Superindo) dan beberapa penyedia makanan gerobag di sekitar kawasan museum (narasumber, 2013).

Penilaian keempat adalah kejelasan petujuk arah yang berada dalam ruan pameran museum. Penilaian dari responden pada poin ini cenderung baik. Hal tersebut dikarenakan adanya kesadaran dari pengelola museum terhadap kebiasaan beberapa pengunjung yang ingin menikmati koleksi museum tanpa didampingi pemandu. Seorang responden individual mengungkapkan bahwa kunjungannya di museum ini bukan kunjungan pertamanya dan pengunjung tersebut datang kembali hanya untuk menikmati koleksi museum tersebut. Penilaian pada poin terakhir berkaitan dengan penilaianpenilaian sebelumnya. Persentase kepuasan dan ketidak puasan responden terhadap kecukupan ketersediaan fasilitas tidak signifikan. Jumlah tersebut dikarenakan kondisi beberapa fasilitas yang tidak tersedia seperti tempat penjualan makanan dan minuman dan kondisi toilet yang kurang baik (Narasumber, 2013).

\subsection{Pelayanan Pemanduan untuk Pengunjung Museum}

Pelayanan merupakan suatu hal penting di destinasi wisata. Keberadaan pelayanan dapat membuat pengunjung merasa nyaman dan diperhatikan. Pelayanan yang diberikan oleh museum adalah 
pelayanan dalam bentuk pemanduan oleh staff museum atau anggota TNI yang sedang bertugas. Tabel di bawah ini merupakan perasaan wisatawan terhadap pelayanan di Museum Dharma Wiratama.

Tabel 6. Kepuasan Terhadap Pelayanan Pemanduan

\begin{tabular}{|c|c|c|c|c|}
\hline & Pelayanan Pemanduan & Puas & Cukup & $\begin{array}{c}\text { Tidak } \\
\text { puas }\end{array}$ \\
\hline A & Keramahan staf museum & 83 & 17 & 0 \\
\hline B & $\begin{array}{c}\text { Keramahan dan } \\
\text { kesopanan pemandu }\end{array}$ & 88 & 12 & 0 \\
\hline C & $\begin{array}{c}\text { Penampilan } \\
\text { pemandu museum }\end{array}$ & 83 & 17 & 0 \\
\hline D & Kejelasan pemanduan & 74 & 26 & 0 \\
\hline E & $\begin{array}{c}\text { Pengetahuan pemandu } \\
\text { mengenai museum }\end{array}$ & 74 & 26 & 0 \\
\hline
\end{tabular}

Sumber: Analisis, 2013

Berdasarkan tabel di atas dapat diketahui bahwa sebagian besar wisatawan telah merasa puas terhadap pelayanan pemanduan yang diberikan museum. Pemandu di museum ini sebagian menggunakan seragam Angkatan Darat untuk para prajuritnya dan sebagian lainnya menggunakan seragam staf untuk para pegawai negeri sipil. Penampilan pemandu di sini berbeda dengan museum pada umumnya karena pemandu di museum ini mengenakan pakaian tentara ataupun Pegawai Negeri Sipil. Persentase tertinggi terdapat pada poin kedua yaitu keramahan dan kesopanan pemandu sebesar 88 persen. Keramahan dan kesopanan dari pemandu meseum dihasilkan dari pelatihan dan sosialisasi kepada staff setempat akan pentingnya keramahtamahan terhadap wisatawan (Pengelola, 2013).

\subsection{Hambatan dan Tantangan Pengelolaan Destinasi Wisata}

Hambatan dan tantangan pengelolaan dihadapi oleh setiap objek wisata. Perlunya mengetahui hambatan dan tantangan adalah untuk mengetahui pengembangan yang dapat dilakukan srta memilimalkan datangnya keluhan dari pengunjung. Hambatan dan tantangan pengelolaan museum ini antara lain:

\subsection{Peraturan dan Kebijakan}

Museum ini memiliki fasilitas cukup untuk memenuhi kebutuhan pengunjungnya, namun fasilitas ini nampaknya harus ditambah sebagai penunjang peningkatan kepuasan pengunjung khususnya pengunjung rombongan. Pengunjung rombongan sangat menyayangkan tidak adanya kantin di museum ini, sehingga mereka kesusahan ketika mereka tidak membawa bekal sendiri. Hal ini dirasakan oleh salah satu responden dari kunjungan rombongan. Dari pihak museum sendiri memang sempat mengajukan untuk pengadaan kantin kecil untuk para pengunjung yang datang, namun hal ini tidak disetujui oleh Disjarahad selaku pemegang keputusan segala pengembangan yang akan dilakukan di museum yang berada dibawah tangan mereka. Penolakan untuk pengadaan kantin ini dikarenakan museum ini merupakan museum milik TNI AD yang berbeda dengan museum pada umumnya, pengawasan museum ini lebih ketat karena memang tidak boleh sembarangan orang memasuki ruangan-ruangan tertentu di museum ini. Namun peraturan pengembangan museum ini tidak terlulis, pengembangan yang akan dilakukan diajukan kepada Disjarahad dan kemudian baru dapat diketahui pengembangan tersebut boleh atau tidak untuk dilakukan. Disjarahad juga melarang adanya komersialisasi pada museum ini. Hal ini memang ide yang baik, namun hal tersebut berbeda konsep dengan pengadaan kantin sebagai fasilitas tambahan. Penjualan makanan atau minuman dengan harga wajar atau sesuai harga eceran yang disarankan nampaknya bukan suatu komersialisasi, kecuali mereka menjual makanan dan minuman dengan harga yang tinggi seperti yang biasa terjadi di destinasi-destinasi wisata. Namun ketidaktersediaan kantin ini tidak menjadi permasalahan bagi sebagian pengunjung individual. Alangkah lebih baiknya apabila pengelola memikirkan kedua tipe pengunjung ini.

\subsection{Aksesibilitas Museum Pusat TNI AD Dharma Wiratama}

\subsubsection{Arah lalu lintas kurang strategis (satu arah)}

Secara geografis, museum ini sebenarnya sudah sangat strategis karena berada di tengah kota, di sekitar tempat pendidikan seperti kampus, 
sekolah, dan perpustakaan. Namun museum ini selalu nampak sepi dan tidak seramai museum lain yang sama-sama dibawah kepengurusan Disjarahad. Untuk sebuah destinasi wisata, ternyata letak strategis secara geografis saja tidak menjadi jaminan akan banyak didatangi pengunjung. Masih banyak faktor lain yang mempengaruhi jumlah kunjungan, salah satunya letak destinasi wisata yang lain. Keadaan ini dialami oleh Museum Dharma Wiratama yang hanya memiliki letak strategis secara geografis, namun di sekitarnya tidak terdapat destinasi wisata lain terutama destinasi wisata unggulan dari Yogyakarta. Sebagian tour baik dari sekolah maupun bukan lebih memilih mengunjungi Museum Jendral Sudirman. Pilihan ini ditetapkan dengan pertimbangan efektifitas waktu kunjungan. Dengan mengunjungi Museum Jendral Sudirman, perjalanan tidak perlu banyak memutar jalan untuk tiba di destinasi lainnya, jalan dari museum ini juga nantinya akan melewati Malioboro. Sedangkan apabila mengambil pilihan untuk mengunjungi Museum Dharma Wiratama, jarak yang akan ditempuh untuk mencapai destinasi lainnya akan cukup jauh apalagi tempat pintu masuk museum yang berada di jalan searah. Kendaraan yang berasal dari arah barat (Tugu Jogja), utara (bundaran UGM), dan selatan (Stadion Kridosono) harus memutar arah untuk memasuki museum ini. Hal tersebut dirasa cukup sulit terutama untuk kendaraan besar.

\subsubsection{Tempat parkir}

Salah satu fasilitas yang tidak kalah penting adalah ketersediaan kawasan parkir. Museum Dharma Wiratama memiliki kawasan parkir yang sangat luas. Kawasan parkir ini juga digunakan bersama dengan karyawan Toko Buku Gramedia. Sebenarnya hal ini bukan menjadi permasalahan yang besar karena walaupun digunakan bersama kawasan parkir ini masih sangat cukup kalau pun terdapat kunjungan rombongan dengan busbus besar. Permasalahannya di sini di rasakan oleh pengunjung yang menggunakan kendaraan bermotor. Hampir semua pengunjung yang datang memarkirkan kendaraannya ditempat parkir yang digunakan sebagai tempat parkir karyawan Gramedia. Belum ada petunjuk yang jelas lokasi parkir untuk pengunjung bermotor.

\subsection{Informasi Mengenai Museum Pusat TNI AD Dharma Wiratama}

\subsubsection{Retribusi}

Museum Dharma Wiratama memiliki keunggulan dalam segi retribusi. Pengunjung yang datang ke museum ini tidak dipungut biaya. Hal ini dapat menjadi nilai lebih atau kekuatan untuk dapat mengembangkan museum ini. Namun, keunggulan ini cenderung tidak diketahui oleh calon pengunjung. Ketidaktahuan calon pengunjung diperoleh berdasarkan wawancara di luar area museum.

\subsubsection{Kepemanduan}

Salah satu pelayanan utama di museum ini adalah penyediaan pemandu wisata. Pengunjung yang akan berkunjung ke museum ini diwajibkan untuk mengisi buku tamu. Pengelola menawarkan jasa pemanduan kepada pengunjung yang sedang mengisi buku tamu. Namun, tidak sedikit pengunjung yang menolak tawaran tersebut akibat ketidakjelasan tarif pemanduan. Pengunjung yang dating cenderung tidak mengetahui bahwa fasilitas pemanduan di museum ini tidak dipungut biaya.

\subsection{Arahan Konsep Pengembangan Museum Pusat TNI AD Dharma Wiratama}

Arahan konsep pengembangan museum disarankan berdasarkan karakteristik pengunjung dan museum, lokasi, dan masukan responden berdasarkan pengalaman kunjungan. Pengembangan pada museum ini perlu dilakukan untuk meningkatkan kepuasan wisatawan, sehingga jumlah kunjungan diharapkan akan meningkat. Pengembangan ini juga dilakukan agar museum ini bisa lebih berkembang dan lebih menarik. Pengembangan juga diperlukan agar Museum TNI AD dapat lebih bersaing dengan museum lain yang berada di Yogyakarta dan sekitarnya. Oleh karena itu, arahan pengembangan ditujukan sesuai konsep objek wisata tersebut.

\subsubsection{Arah Konsep Pengembangan Produk}

Produk wisata pada museum ini adalah bendabenda koleksi bersejarah yang berhubungan dengan perjuangan TNI AD dalam memperjuangkan kemerdekaan. Benda koleksi di museum ini terawat dan dalam kondisi yang baik. Setiap benda koleksi memiliki informasi tertulis mengenai sejarah benda 
tersebut. Namun, penyajian informasi ini kurang menarik karena tulisan dengan ukuran huruf yang cenderung sulit untuk dibaca. Informasi pada benda koleksi yang lebih lengkap serta lebih menarik dapat mempermudah pengunjung dalam memahami koleksi dan pengunjung akan lebih tertarik untuk membaca informasi tersebut dengan ukuran huruf yang lebih besar. Museum ini memiliki koleksi yang istimewa yaitu berupa panser atau tank yang dipajang di area parkir. Koleksi tersebut dapat diumanfaatkan sebagai penambah daya tarik bagi pengunjung anak-anak serta dewasa untuk berfoto di kendaraan tersebut.

\subsubsection{Arah Konsep Pengembangan Fasilitas}

Kepuasan pengunjung terhadap keberadaan fasilitas di Museum TNI AD tidak terlalu baik. Museum perlu meningkatkan kualitas fasilitas yang telah tersedia seperti kamar mandi, toliet, tempat parkir, dan koperasi. Pengembangan fasilitas di museum ini sangat terbatas akibat adanya keperaturan dari Disjarahad, sehingga penambahan fasilitas penunjang kurang memungkinkan. Berdasarkan faktor tersebut, museum dapat membantu kebutuhan wisatawan dengan memberikan penunjuk atau papan informasi, sehingga pengunjung dapat lebih mudah mendapatkan fasilitas yang tidak disediakan di dalam kawasan museum.

\subsubsection{Arah Konsep Pengembangan Pelayanan}

Standar pelayanan yang baik telah diterapkan oleh beberapa staf dan pemandu di museum ini namun, empati kepada pengunjung dari pihak museum belum maksimal. Hal tersebut dibuktikan dengan adanya rasa ketidaktahuan pengunjung terhadap adanya jasa pelayanan pemanduan tanpa dipungut biaya. Ketiadaan informasi pemanduan tersebut mengakibatkan munculnya segan bagi wisatawan untuk bertanya ketersediaan pemandu beserta tarif pemanduan. Oleh karena itu, pihak penerima tamu sebaiknya memberikan informasi dengan detail bukan hanya peraturan untuk memasuki museum saja.

Keramahan sebagian besar staf dan pemandu museum ini menjadi nilai lebih untuk museum ini. Rasa empati dari pemandu dan staf sebaiknya ditingkatkan untuk membuat pelayanan menjadi lebih maksimal. Selain itu, keberadaan pemandu yang lebih interaktif dapat membuat pengunjung tidak bosan selama berada di museum.

\section{Kesimpulan}

Pengunjung Museum Pusat TNI AD Dharma Wiratama sudah merasa puas terhadap kualitas produk dan pelayanan dari pihak museum, namun tingkat kepuasan pengunjung terhadap fasilitas kurang baik. Kurangnya tingkat kepuasan pengunjung terhadap ketersediaan fasilitas berkaitan dengan adanya peraturan dari Disjarahad. Peraturan tersebut membatasi pengelola museum dalam mengembangkan ketersediaan fasilitas untuk menunjang kebutuhan wisatawan. Permasalahan tersebut dapat ditekan dengan pemberian papan informasi atau papan penunjuk di area museum sehingga wisatawan dapat memenuhi kebutuhan perjalanan ketika ataupun setelah kunjungannya. Dominasi karakteristik pengunjung di museum ini adalah pelajar. Hal tersebut dapat dimanfaatkan untuk meningkatkan jumlah kunjungan dengan cara meningkatkan pelayanan pemanduan sehingga pengunjung yang merupakan pelajar dapat memperoleh ilmu setelah kunjungan. Karakteristik pengunjung museum yang didominasi pelajar serta lokasi yang berdekatan dengan pusat mendidikan menjadikan Museum Pusat TNI AD berpeluang besar sebagai salah satu destinasi wisata pendidikan sejarah bersaing di Yogyakarta.

\section{Referensi}

Anonim. (1982). "Museum Pusat TNI-AD Dharma Wiratama”. Dinas Sejarah TNI Angkatan Darat.

Anonim. "Panduan Singkat Museum TNI-AD Dharma Wiratama". Dinas Sejarah Angkatan Darat.

Badudu, J.S. dan Sutan Mohammad Zain. (2001). Kamus Umum Bahasa Indonesia. Jakarta: Pustaka Sinar Harapan.

Gage, Susan M. (2006). Seri Manajemen; Strategi Pelayanan Pelanggan. Yogyakarta: ARGO Publisher.

Hadiasmara, Hendrarto. (1992). Pedoman Pemeliharaan dan Pemugaran Bangunan Museum. Jakarta: Proyek Pembinaan Permuseuman Jakarta.

Ismanto, Doni. (2007). “Analisis Tingkat Kepuasan Wisatawan di ODTW Kaliurang dalam Upaya Peningkatan Kualitas Produk dan Layanan Wisata". Tesis. Program Pascasarjana. Universitas Gadjah Mada. Yogyakarta. 
Kiswanto, Fansisca Purwitasanti. (2011). "Kepuasan Pengunjung Terhadap Jasa Wisata Pendidikan Taman Pintar Yogyakarta”. Skripsi. Fakultas Ekonomi Universitas Sanata Dharma. Yogyakarta.

Kusmayadi, Endar Sugiarto. (2000). Metodologi Penelitian dalam Bidang Kepariwisataan. Jakarta: Gramedia Pustaka Utama.

Marsono. (2008)."Bahan Kuliah Pengantar Pariwisata". Program Studi Pariwisata UGM. Yogyakarta.

Data Kunjungan Museum Pusat Angkatan Darat Dharma Wiratama tahun 2013

Museum Pusat Angkatan Darat. (2013). "Naskah Sekolah Sementara tentang Organisasi dan Administrasi Museum SUSPAMUSTAKTRA".

Pitana, I Gede \& Putu G Gayatri. (2005). Sosiologi Pariwisata. Yogyakarta: ANDI.

Pitana, I Gede dan I Ketut Surya Diarta. (2009). Pengantar Ilmu Pariwisata. Jakarta: ANDI.

Pusat Bahasa Depdiknas. (2005). Kamus Besar Bahasa Indonesia (edisi ketiga). Jakarta: Balai Pustaka.

Rahardiyan, Rifki dan Yulius Jaka Prasetya. (2008). "Museum TNI-AD Wiratama Sebagai Objek Wisata Budaya di Provinsi Daerah Istimewa Yogyakarta”. Tugas Akhir. Fakultas Ilmu Budaya. Universitas Gadjah Mada. Yogyakarta.

Prajarto, Nunung. (2006). Tulis Saja, Kapan Lagi Dasar Aplikasi Komunikasi Tertulis. Yogyakarta: FISIPOL UGM.

Rangkuti, Freddy. (2006). Measuring Costumer Satisfaction: Gaining Customer Relationship Strategy Teknik Mengukur dan Strategi Meningkatkan Kepuasan Pelanggan \& Analisis Kasus PLN-JP. Jakarta: Gramedia.

Ross, F Glenn. (1998). Psikologi Pariwisata. Jakarta: Yayasan Obor Indonesia.

Sutaarga, Moh. Amir. (1997). Pedoman Penyelenggaraan dan Pengelolaan Museum. Jakarta. Proyek Pembinaan Permuseuman Jakarta.

Syahmi, Mahfuzh. (2005). "Analisis Kepuasan Wisatawan yang Berkunjung ke Wanawisata dan Air Terjun Coban Rondo Kab Malang”. Skripsi. Fakultas Kehutanan UGM. Yogyakarta.

Tnunay, Tontje. (1991). Yogyakarta Potensi Wisata. Klaten: CV SAHABAT Klaten.

Undang-Undang RI No. 10 Tahun 2009 tentang Kepariwisataan.

Utama, I Gede Bagus Rai dan Ni made Eka Mahadewi. 2012. Metodologi Penelitian Pariwisata \& Perhotelan. Denpasar: ANDI.

Wahab, Salah. (2003). Manajemen Kepariwisataan. Jakarta: Pradnya Paramita.

Wahyudi, Dedy Hendra. (2008). "Evaluasi Terhadap Manajemen Permuseuman di Museum Pusat TNIAD Dharma Wiratama”. Skripsi. Fakultas Ilmu
Budaya. Universitas Gadjah Mada. Yogyakarta. Wardiyanta. (2006). Metode Penelitian Pariwisata. Yogyakarta: ANDI.

Widayanta, Heru. (2007). "Pengaruh Kualitas Pelayanan Terhadap Kepuasan Pelanggan Pada Hotel Laras Asri Resort dan Spa Salatiga". Tesis. Magister Arsitektur Pariwisata. Universitas Gadjah Mada. Yogyakarta.

Warpani, Suwardjoko P dan Indira P Warpani. (2007). Pariwisata dalam Tata Ruang Wilayah. Bandung: ITB Bandung.

Yoeti, Oka A. (1982). Pengantar Ilmu Pariwisata. Bandung: Angkasa.

Yoeti, Oka A. (1999). Psikologi Pelayanan Pariwisata. Jakarta: Gramedia.

Yoeti, Oka A et.al. (2006). Pariwisata Budaya: Masalah dan Solusinya. Jakarta: Pradnya Paramita.

\section{Pustaka Laman}

http://id.wikipedia.org/wiki/Museum_Pusat_TNI AD_\%22Dharma_Wiratama\%22 diakses pada 21 November 2013 pukul 19.17

http://teorionline.wordpress.com/2010/01/24/populasidan-sampel/ diakses pada 13 Juni 13 pukul 12.10

http://belajaritutiadaakhir.blogspot.com/2011/08/ museum-di-indonesia.html diakses pada 10 Februari 2014 pukul 06.00 